\title{
The Effect of Perceived Service Quality on Customer Satisfaction in Private Commercial Banks of Ethiopia: The Case of Selected Private Commercial Banks at Dire Dawa Administration
}

Jonathan B Dawit* and Ubah Adem

College of Business and Economics, Dire Dawa University, Ethiopia

\begin{abstract}
Financial and banking service has become more vital for the development of an economy especially for the developing country like Ethiopia. All Ethiopian commercial banks, whether public or government, compete on quality service to satisfy the customers to win and sustain in the competition. This study focus to study the effect of perceived service quality on customer satisfaction in private commercial banks of Ethiopia. To realize this, 375 respondents was taken from 10 private commercial banks via self-administer questionnaires. Customers was agreed and satisfied on service quality dimensioned delivered by their respective banks. Multiple regression result showed that Empathy, Reliability and Responsiveness predicted $61.2 \%$ of variation on customer satisfaction.
\end{abstract}

Keywords: Service quality; SERVPERF; Customer satisfaction

\section{Introduction}

The financial and banking service has become more vital for the development of an economy. Banks play very important role for the economic development of a country. Over hundred year history of banking in Ethiopia, the country reached to 18 banks at the end of 2016. Ethiopia has a total of 16 private banks and 2 public banks with a total of 3187 branches and 43 billion birr capital. As a result, bank branch to population ratio revolves around 1:28,932 [1].

All Ethiopian commercial banks, whether private or public, compete on quality service to satisfy the customers to win and sustain in the competition. Quality spells superiority or excellence [2]. A bank can differentiate itself from competitors by providing high quality customer service [3]. To realize these, banks need to know whether perceived service quality dimensions affect customer satisfaction or not. They also need to identify which service quality dimensions mostly affect customer satisfaction.

\section{Objective of the Study}

The main objective of this research was to study the effect of perceived service quality on customer satisfaction in private commercial banks in Ethiopian; the case of selected private commercial banks at Dire Dawa Administration.

\section{Review Literature}

Quality defined in terms of product or service usefulness for the price paid is a definition of quality that consumers often use for product or service usefulness. This is the only definition that combines economics with consumer criteria; it assumes that the definition of quality is price sensitive [4]. Service quality also defined as the result of the comparison made by customers about what they feel service firms should offer, and perceptions of the performance of firms providing the services [5].

Customer satisfaction defined as the customers' evaluation of a product or service in terms of whether that product or service has met their needs and expectations [2]. Customer satisfaction in broader sense defined as consumers feeling and happiness after complete meeting of one's expectations.

The service quality of banking services provided to customers have been enhanced and it can be used as a prime weapon to realizing service excellence to win competition, where legendary service has become the basis for differentiation between the banks. Under dynamic business environment, banks are seeking to reach beyond the quality by providing a distinguishing banking services, creating a sense of satisfaction to the customer through the service acquired and met their anticipation [6].

Luka, Andrew and Felishman studied the effect of quality financial service on customer satisfaction by commercial banks in Kenya. The result shows that majority of the customers' are male and they are categorized under the age between 18-30 years. The study shows that except tangibility, other service dimensions determine $72.6 \%$ of variations on customer satisfaction. In addition, they reveals that all service dimension have position relationship with customer satisfactions (Luka, Effect of quality financial service on customer satisfaction by Commercial Banks in Kenya, 2015).

Tizazu in his article entitled the effect of customer service quality on customer satisfaction in selected private banks in Addis Ababa use with structured questionnaire using SERVQUAL model, which targeted 342 private banks customer. The result indicated that unlike responsiveness the four service quality dimensions (tangibility, empathy, assurance and reliability) have positive and significant effect on customer satisfaction. Furthermore, the service quality dimensions (tangibility, reliability, assurance and empathy) significantly explain $80 \%$ of the variations in customer satisfaction in private banks in Addis Ababa [7].

Shanka in his article entitled bank service quality, customer satisfaction and loyalty in Ethiopian banking sector covered 260 customers of 13 private banks (operated in Hawasa City administration) using SERVPERF model of structured questionnaire. The results of

*Corresponding author: Dawit JB, College of Business and Economics, Dire Dawa University, Ethiopia, Tel: +251 25111 8682; E-mail: dd47334@gmail.com

Received May 24, 2017; Accepted June 22, 2018; Published June 29, 2018

Citation: Dawit JB, Adem U (2018) The Effect of Perceived Service Quality on Customer Satisfaction in Private Commercial Banks of Ethiopia: The Case of Selected Private Commercial Banks at Dire Dawa Administration. Bus Eco J 9 : 358. doi: 10.4172/2151-6219.1000358

Copyright: $\odot 2018$ Dawit JB, et al. This is an open-access article distributed under the terms of the Creative Commons Attribution License, which permits unrestricted use, distribution, and reproduction in any medium, provided the original author and source are credited. 
this study showed that majority of banks customers' are male, degree holders and categorized under the age between 18-30 years. All service quality dimensions are positively correlate with customer satisfaction but empathy score lowest mean value. The research findings also indicate that only empathy, responsiveness and assurance have significant and positive effect on customer satisfaction. Conversely, reliability and tangibility dimensions have no significant effect on customer satisfaction [8] (Figure 1).

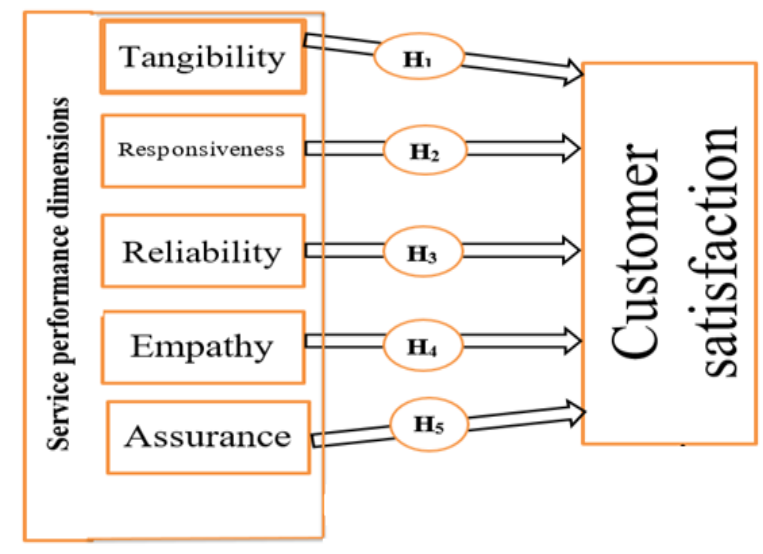

Figure 1: Theoretical framework.

\section{Research Methodology}

\section{Research design}

The study was quantitative type in nature that includes both descriptive and explanatory design. Describing the existing situation under the study was descriptive where explaining, understanding and predicting the relationship between variables was explanatory design.

\section{Target sample size}

The target population for the study were the customers of 10 private commercial banks functioning in Dire Dawa administration. One hundred forty five thousand five hundred seventy eight $(145,578)$ customers of private commercial banks taken as sample population.

\section{Data collection instruments}

Self-administered questionnaires were the main instrument of data collection based on SERVPERF model. The scale consists of 22 perception items excluding any consideration of expectations.

The questionnaires were issued randomly to respondent based on stratified sampling techniques to customers of 10 private commercial banks at the banking hall. The questionnaire designed into three parts to explore the required information. A five point Likert scale was used to measure each question, with 1-Strongly Disagree, 2-Disagree 3-Neutral, 4-Agree, and 5-strongly agree.

\section{Data processing and analysis}

The data collected from the respondents was coded into SPSS V23 for data analysis. Normality test checked before the data analyzed. Descriptive statistics was done to characterize the demographic information of respondents while inference statistics, Regression analysis, was done to predict the effect of service quality dimension on customer satisfaction.

Multiple regression was used to find the effect of service quality on customer satisfaction because this was an antecedent relation within them. The multiple regression equation was used to describe the relationship between independent variables (Tangibility, reliability, responsiveness, assurance, and empathy) and dependent variables (customer satisfaction), how much independent variable determines the dependent variables?

Mathematically, $C S=\beta_{1}+\beta_{2}(\mathrm{TA})+\beta_{3}(\mathrm{RL})+\beta_{4}(\mathrm{RS})+\beta_{5}(\mathrm{AS})+\beta_{6}(\mathrm{EM})+\varepsilon$ Where

CS is the dependent variable (customer satisfaction)

TA, RL, RS, AS, and EM are independent variables which denoted Tangibility, Reliability, Responsiveness, Assurance and Empathy respectively.

$\beta_{1}$ is intercept of Customer Satisfaction, its mechanical interpretation is the average value of Customer Satisfaction when the stated independent variables are set equal to zero.

$\beta_{2} \beta_{3} \beta_{4} \beta_{5} \beta_{6}$ are the coefficients of Service Quality dimensions their respective independent variables, which measures the change in the mean value of Customer Satisfaction, per unit change in their respective independent variables

$\varepsilon$ is error term

\section{Variables of the Study}

The focus variable of this study explained as follow.

1. Tangibles: the appearance of physical facilities, equipment, personnel and communication materials. The customer perceives that all the tangible aspects of the service are fit for the task and is customer friendly.

2. Reliability: the ability to perform the promised service dependably and accurately.

3. Responsiveness: the willingness to help customers and provide prompt service. The customer's perception that the service provider responds quickly and accurately to his or her specific needs and demands.

4. Assurance: the knowledge and courtesy of employees and their ability to convey trust and confidence so that the customer feels he or she is in courteous, able and competent hands.

5. Empathy: providing caring and individualized attention for customers to make them feel they are receiving caring services and individualized attention.

6. Customer satisfaction defined as the consumer's sense that consumption provides outcomes against a standard of pleasure versus displeasure.

\section{Hypothesis of the Study}

The researcher proposed five hypotheses that relate with research objectives. The research null and alternative hypothesis presented as follow:

1. Hypothesis $1\left(\mathrm{H}_{\mathrm{ol}}\right)$ : Tangibles does not have significant effect on customer satisfaction in private commercial banks.

Hypothesis $1\left(\mathrm{H}_{\mathrm{a}}\right)$ : Tangibles does have significant effect on customer satisfaction in private commercial banks. 
Citation: Dawit JB, Adem U (2018) The Effect of Perceived Service Quality on Customer Satisfaction in Private Commercial Banks of Ethiopia: The Case of Selected Private Commercial Banks at Dire Dawa Administration. Bus Eco J 9: 358. doi: 10.4172/2151-6219.1000358

2. Hypothesis $2\left(\mathrm{H}_{\mathrm{o} 2}\right)$ : Reliability does not have significant effect on customer satisfaction in private commercial banks.

Hypothesis $2\left(\mathrm{H}_{\mathrm{a} 2}\right)$ : Reliability does have significant effect on customer satisfaction in private commercial banks.

3. Hypothesis $3\left(\mathrm{H}_{\mathrm{o} 3}\right)$ : Responsiveness does not have significant effect on customer satisfaction in private commercial banks.

Hypothesis $3\left(\mathrm{H}_{\mathrm{a} 3}\right)$ : Responsiveness does have significant effect on customer satisfaction in private commercial banks.

4. Hypothesis $4\left(\mathrm{H}_{\mathrm{o} 4}\right)$ : Assurance does not have significant effect on customer satisfaction in private commercial banks.

Hypothesis $4\left(\mathrm{H}_{\mathrm{a} 4}\right)$ : Assurance does have significant effect on customer satisfaction in private commercial banks.

5. Hypothesis $5\left(\mathrm{H}_{05}\right)$ : Empathy does not have significant effect on customer satisfaction in private commercial banks.

Hypothesis $5\left(\mathrm{H}_{\mathrm{a} 5}\right)$ : Empathy does have significant effect on customer satisfaction in private commercial banks.

\section{Data Analysis and Finding}

\section{Demographic information}

This research was bounded on the main demographic characteristics of Gender, age, educational levels and years of customer-ship with bank. Table 1 revealed that the majority of the respondent was male, age between 18-28 yeas gaps and customer for their respective bank of $1-5$ years.

\section{Analysis of service quality dimension and customer satisfaction}

Perceived service quality dimensions and customer satisfaction mean score are presented in Table 2. From the five attributes of service quality dimension, assurance score highest mean (4.04) followed by Empathy (4.02), Responsiveness (3.98), Tangibility (3.88) and reliability (3.84). Customer satisfaction mean score was 3.99. This revealed that customer was agreed by the level of service quality delivered by private commercial banks. Customers of private commercial banks was satisfied by the service delivered by their respective banks. When Ravethi and Saranya [9], Ubah [10], Khan and Fasih [11], Mohammad

\begin{tabular}{|c|c|c|c|}
\hline \multicolumn{2}{|c|}{ Demographic Characteristics } & \multirow{2}{*}{$\begin{array}{c}\text { Frequency } \\
241\end{array}$} & \multirow{2}{*}{$\begin{array}{c}\text { Percent } \\
64.3\end{array}$} \\
\hline Gender & Male & & \\
\hline & Female & 134 & 35.7 \\
\hline \multirow[t]{4}{*}{ Age } & $18-28$ & 228 & 60.8 \\
\hline & $29-38$ & 117 & 31.2 \\
\hline & $39-48$ & 245 & 6.7 \\
\hline & $49-58$ & 5 & 1.3 \\
\hline \multirow[t]{6}{*}{$\begin{array}{l}\text { Highest Educational } \\
\text { Level }\end{array}$} & $\begin{array}{l}\text { Elementary school and } \\
\text { below }\end{array}$ & 24 & 6.4 \\
\hline & High school & 70 & 18.7 \\
\hline & Certificate & 22 & 5.9 \\
\hline & Diploma & 89 & 23.7 \\
\hline & Bachlor degree & 153 & 40.8 \\
\hline & Master degree and above & 17 & 4.5 \\
\hline \multirow[t]{3}{*}{ Year of customer ship } & Less than one year & 88 & 23.5 \\
\hline & $1-5$ years & 180 & 48 \\
\hline & $6-10$ years & 65 & 17.3 \\
\hline Total & & 375 & 100 \\
\hline
\end{tabular}

Table 1: Demographic information of respondent. and Alhamadani [12] on their research finding revealed that tangibility and reliability scored less mean values compared to other dimensions, which is supported by this research. Contrary, Empathy and assurance scored highest mean, which is supported by, Abiyot and Gemechu [13], Khan and Fasih [11], and Shanka [8]. Toward customer satisfaction, this result was consistent with a research result studied by Mohammad and Alhamadani [12] at Jordan commercial banks.

\section{Analysis of regression output}

As the below Table 3 shows the multiple linear regression model summary and overall fit statistics. It was found that adjusted $\mathrm{R}^{2}$ of the model is 0.612 with the $\mathrm{R}^{2}=0.612$. This means that the multiple linear regression model with the independent variable empathy, reliability and responsiveness explains $61.2 \%$ of the variance of the customer satisfaction this value of $\mathrm{R}^{2}$ was similar with research result performed by Luka $[11,14]$.

Table 4 shows that, multiple linear regression coefficient estimates including the intercept and the significance levels. In the model, there is non-significant intercept but also highly significant coefficients for empathy, reliability and responsiveness. The regression equation would be $\mathrm{CS}=0.462+0.395 \mathrm{EM}+0.282 \mathrm{Rl}+0.216 \mathrm{RS}$. For every additional increase of reliability, there is 0.395 increase in customer satisfaction, while for additional increase of reliability and responsiveness; there is 0.282 and 0.216 increase in customer satisfaction respectively.

Based on the data presented in the above Table 4 described that the multiple regression coefficients, null hypothesis $\mathrm{H}_{02}, \mathrm{H}_{03}$ and $\mathrm{H}_{05}$ are rejected at $95 \%$ level of confidence. It has been found that empathy $(\beta=0.395, \mathrm{t}=6.934, \mathrm{p}<0.001)$, reliability $(\beta=0.281, \mathrm{t}=5.334, \mathrm{p}<0.001)$ and responsiveness $(\beta=0.216, t=3.315, p<0.001)$ significantly influence customer satisfaction. And also the variables tangibility $(\beta=0.11$, $\mathrm{t}=0.228, \mathrm{p}>0.05)$ and assurance $(\beta=0.53, \mathrm{t}=0.853, \mathrm{p}>0.05)$ were found insignificant to influence customers satisfaction of private commercial banks. This supported to accept null hypothesis $\left(\mathrm{H}_{01}\right.$ and $\left.\mathrm{H}_{04}\right)$ that that tangibility and assurance had no effect on customer satisfaction in private commercials banks.

The result evident that only empathy, reliability and responsiveness had positive effect of customer satisfaction at $5 \%$ level of significance. Empathy was the main determinant of customer satisfaction that is consistent with Abiyot and Gemechu [13], and Shanka [8]. Tangibility had insignificant effect on customer satisfaction in private commercial banks that are consistent with Abiyot and Gemechu [13], Ravichandran

\begin{tabular}{|l|c|c|c|}
\hline Service Quality dimensions & Mean & $\begin{array}{c}\text { Std. } \\
\text { Deviation }\end{array}$ & N \\
\hline Tangibility & 3.88 & 0.776 & 375 \\
\hline Reliability & 3.84 & 0.805 & 375 \\
\hline Responsiveness & 3.98 & 0.817 & 375 \\
\hline Assurance & 4.04 & 0.777 & 375 \\
\hline Empathy & 4.02 & 0.793 & 375 \\
\hline Service Quality (pooled mean) & 3.95 & 0.699 & 375 \\
\hline Customer satisfaction & 3.99 & 0.833 & 375 \\
\hline
\end{tabular}

Table 2: Mean value of service quality and customer satisfaction.

\begin{tabular}{|c|c|c|c|c|c|}
\hline Model & $\mathbf{R}$ & $\begin{array}{c}\mathbf{R} \\
\text { Square }\end{array}$ & $\begin{array}{c}\text { Adjusted R } \\
\text { Square }\end{array}$ & $\begin{array}{c}\text { Std. Error of the } \\
\text { Estimate }\end{array}$ & $\begin{array}{c}\text { Durbin- } \\
\text { Watson }\end{array}$ \\
\hline 1 & $.785^{\mathrm{a}}$ & 0.616 & 0.612 & 0.5187 & 1.795 \\
\hline \multicolumn{7}{|l}{} \\
aPredictors: (Constant), Empathy, Reliability, Responsiveness \\
bependent Variable: Customer satisfaction
\end{tabular}

Table 3: Model summary ${ }^{b}$ 
Citation: Dawit JB, Adem U (2018) The Effect of Perceived Service Quality on Customer Satisfaction in Private Commercial Banks of Ethiopia: The Case of Selected Private Commercial Banks at Dire Dawa Administration. Bus Eco J 9: 358. doi: 10.4172/2151-6219.1000358

Page 4 of 4

\begin{tabular}{|c|c|c|c|c|c|c|c|c|c|}
\hline \multirow[t]{2}{*}{ Model } & \multicolumn{2}{|c|}{ Unstandardized Coefficients } & \multirow{2}{*}{$\begin{array}{c}\text { Standardized Coefficients } \\
\text { Beta }\end{array}$} & \multirow[t]{2}{*}{$\mathbf{t}$} & \multirow[t]{2}{*}{ Sig. } & \multicolumn{2}{|c|}{$95.0 \%$ Confidence Interval for B } & \multicolumn{2}{|c|}{ Co-linearity Statistics } \\
\hline & B & Std. Error & & & & Lower Bound & Upper Bound & Tolerance & VIF \\
\hline (Constant) & 0.462 & 0.147 & & 3.14 & 0.002 & 0.173 & 0.752 & & \\
\hline Empathy & 0.395 & 0.057 & 0.376 & 6.934 & 0 & 0.283 & 0.507 & 0.353 & 2.835 \\
\hline Reliability & 0.282 & 0.053 & 0.272 & 5.334 & 0 & 0.178 & 0.386 & 0.397 & 2.516 \\
\hline Responsiveness & 0.216 & 0.056 & 0.211 & 3.815 & 0 & 0.104 & 0.327 & 0.338 & 2.963 \\
\hline
\end{tabular}

Table 4: Regression coefficients.

et al., [15], Khan and Fasih [11], Shanka [8]. In addition, assurance had insignificant effect on customer satisfaction in private commercial banks that are consistent with and Abiyot and Gemechu [13], and Ravichandran et al., [15], Meuter et al. [16].

\section{Conclusion}

Customers agreed on the standard of service quality delivered by their respective banks. The mean score of service quality and customer satisfaction attributes varies between 3.57 and 4.17; which implies that customers agreed and satisfied on the standard of service quality delivered by the private commercial banks. The regression output showed that $61.2 \%$ of customer satisfaction variation determined by empathy, responsiveness and reliability Therefore, service quality has positive effect on customer satisfaction. The results of this study concluded that service quality is an important antecedent of customer satisfaction.

\section{References}

1. NBE (2016) Annual report of Ethiopia. Addis Ababa: NBE.

2. Zeithaml V, Bitner M (2000) Service Marketing. New York: McGraw Hill Inc.

3. Naeem H, Asma A, Iqbal SM (2009) Service quality and its impact on customer satisfaction: Am empirical evidence from the pakistan banking sector. Int Bus Econ Res J 8: 99-104.

4. Chase BAj (2002) Production and Operation Management: Manufacturing and service 8th ed. New Delhi: Tata McGraw-Hill plc.

5. Akroush MN (2008) Exploring the mediating effect of service quality implementation on the relationship between service quality and performance in the banking industry in Jordan. Glob Bus Econ Rev, pp: 98-122.
6. Suleiman A (2013) Basic dimension of the SERVQUAL model and iits impact on the level of customer satisfaction: An Em. Eur Sci J.

7. Tizazu K (2014) The Effect of customer service quality on customer satisfaction in selected private banks. Addis Ababa University.

8. Shanka MS (2012) Bank service quality, customer satisfaction and loyality in Ethiopian Banking sector. J Bus Admin Manage Sci Res.

9. Revathi S, Saranya A (2016) Dimension of Serice quality and customer satisfaction: Banking sector. Int J Sci Res Dev.

10. Ubah A (2015) A study on service quality of commercial banks in Dire Dawa Ethiopia: Comparative study of public and private banks. Eur J Bus Manage.

11. Khan MM, Fasih M (2014) Impact of service quality and customer satisfaction and customer loyality: Evidence from banking sector. Pakistan J Commerce Soc Sci 8: 331-354.

12. Mohammad AAS, Alhamadani SYM (2011) Service quality perspectives and customer satisfaction in commercial banks working in Jordan. Middle Eastern Financ Eco.

13. Abiyot TK, Gemechu ND (2016) Service quality, customer satisfaction and loyality of commercial banks in Ethiopia. Int J Innov Sci Res 28: 51-65.

14. Cheserek LK, Kimwolo AK, Cherop F (2015) Effect of quality financial service on customer satisfaction by Commercial Banks in Kenya. Int J Humanities Soc Sci.

15. Ravichandran K, Tamil MB, Sivakumar AK, Sellamuthu $P(2010)$ Influence of service quality on customer satisfaction: application of SERVQUAL model. Int J Bus Manage.

16. Meuter M, Ostrom A, Roundtree R, Bitner M (2000) Self-service Technologies: Understanding Customer Satisfaction with Technology based service. Encounter Market Assoc 64: 50-64. 